\title{
ZAKAT FOR BUSINESS INVESTMENT AS SOCIAL SECURITY
}

\author{
Amin Songgirin, Rizky Dwi Pradana \\ Fakultas Hukum Universitas Pamulang \\ E-Mail: dosen01842@unpam.ac.id
}

\begin{abstract}
Abstrak
Zakat merupakan ibadah māliyah ijtima'iyyah (harta sosial) yang memiliki posisi signifikan, strategis dan menentukan, baik dilihat dari sisi ajaran Islam maupun dari sisi pembangunan kesejahteraan umat. Sebagai suatu ibadah pokok, dalam rukun Islam yang lima (rukun Islam ke tiga), zakat merupakan satu rukun yang bercorak sosial ekonomi. Kedudukan, fungsi dan tujuan zakat sejalan dengan Undang-Undang Dasar 1945, sebagaimana Pasal 34 mengamanahkan sebagaimana dijelaskan dalam ayat-ayat berikut: (1) Fakir miskin dan anak-anak terlantar dipelihara oleh Negara. (2) Negara mengembangkan sistem jaminan sosial bagi seluruh rakyat dan memberdayakan masyarakat yang lemah dan tidak mampu sesuai dengan martabat kemanusiaan. (3) Negara bertanggung jawab atas penyediaan fasilitas pelayanan kesehatan dan fasilitas pelayanan umum yang layak. Potensi zakat di Indonesia apabila dioptimalkan sebesar Rp. 217 triliun rupiah dalam satu tahun. Potensi ini bisa didistribusikan sebagai jaminan sosial untuk kesejahteraan rakyat golongan tidak mampu. Agar tetap berjalan, terus berkembang dan berkelanjutan, penyaluran dana zakat melalui pendekatan investasi usaha. Untuk mengoptimalkan pendapatan zakat, maka pemerintah membuat regulasi melalui undang-undang, setiap orang Islam yang sudah wajib menunaikan zakat secara otomatis mendapat tagihan dan harus membayar di Badan Pengelola Zakat Nasional. Badan Pengelola Zakat Nasional selanjutnya membantuk lembaga usaha (Badan Usaha Zakat), kemudian menginvestasikan dana zakat tersebut pada sektor-sektor strategis, seperti pertanian, perikanan dan perdagangan. Hasil Badan Usaha Zakat selanjutnya didistribusikan kepada kelompok yang berhak mendapatkannya sebagai jaminan sosial di bidang pendidikan, kesehatan, tempat tinggal, jaminan hari tua, dan lain-lain.
\end{abstract}

Kata Kunci: investasi zakat; jaminan sosial; zakat jaminan sosial.

\begin{abstract}
Zakat is a māliyah ijtima'iyyah (social assets) worship that has a significant, strategic, and decisive position, both in terms of Islamic teachings and in terms of the development of the welfare of the people. As the main worship, in the five pillars of Islam (the third pillar of Islam), zakat is a pillar with socio-economic character. The position, function, and purpose of zakat are in line with the 1945 Constitution, as Article 34 mandates as explained in the
\end{abstract}


following verses: (1) The poor and neglected children are cared for by the State. (2) The state develops a social security system for all people and empowers people who are weak and unable to comply with human dignity. (3) The State is responsible for providing adequate health service facilities and public service facilities. Potential of zakat in Indonesia when optimized is 217 trillion rupiahs in one year. This potential can be distributed as social security for the welfare of the poor. To keep going, continue to grow and continue, the distribution of zakat funds through a business investment approach. To optimize zakat income, the government makes regulations through the law, every Muslim who is obliged to pay zakat will automatically receive a bill and must pay at the National Zakat Management Agency. The National Zakat Management Agency further supports business institutions (Zakat Business Entities), then invests the zakat funds in strategic sectors, such as agriculture, fisheries, and trade. The results of the Zakat Business Entity are then distributed to groups who are entitled to get it as social security in the fields of education, health, shelter, old-age insurance, and others.

Keywords: zakat investment; social security; social security zakat.

\section{Introduction}

The stipulation of zakat in the second year of hijriyah (before the mandatory fasting of Ramadan). On the other hand, it is compulsory for zakat in the third year of hijriyah (after the fasting law) after the migration of Prophet Muhammad from Mecca to Medina. ${ }^{1}$ Zakat is the third pillar of Islam that must be paid for gold and silver assets, commerce, livestock, mining and agriculture when the amount has reached the niṣāb (the minimum obligatory limit to pay zakat). ${ }^{2}$

Among the functions of zakat is as a source of funds for economic equality and community development. (as in al-Qur'ān surah al-Hasyr [59]: 7) With zakat, it is a means of relationship (silaturrahmi) between muzakki (capable people) and mustahiq (poor people). ${ }^{3}$ In history, during the time of the Caliph 'Umar Ibn 'Abdul 'Azīz (ruling 99-110 H./717-720 AD), it is said that

${ }^{1}$ Dirjen Bimas Islam Direktorat Pendayagunaan Zakat Kementerian Agama R.I. Modul Penyuluhan Zakat, Dirjen Bimas Islam, Jakarta, 20013, p. 19

${ }^{2}$ Amiruddin, K., Model-Model Pengelolaan Zakat di Dunia Muslim, UIN Sunan Ampel, Surabaya, t.t., p. 3-4

${ }^{3}$ Faidati, Ashima, Pendistribusian Zakat Perdagangan Telur Ayam Petelu: Studi Kasus Desa Punjul Kecamatan Karangrejo Kabupaten Tulungagung, IAIN Tulungagung, Tulungagung t.t., p. 3 
it was difficult to find people who were entitled to receive zakat (mustahiq), because the people's welfare at that time was evenly distributed with one of them through zakat management and is distributed properly through the Bait al-Māl institution. ${ }^{4}$ Perhaps the rise of poverty and social disparities in Islamic countries lately, because zakat has not been fulfilled by the majority of which are obliged to fulfill and not yet optimal management. ${ }^{5}$

Essentially the meaning of zakat is al-barakah (blessing), al-nama (growing and developing), al-țahārah, namely holiness. al-ziyādah (increase) and al-șalāh means benefit. ${ }^{6}$ In the implementation and management of zakat, there is a connection between the assets for which zakat is paid, the person who gives zakat and the person who receives zakat. Blessing, holiness, growing and growing and increasing encompass all three. As purifying the soul for mustahiq from the nature of being stingy, greedy, arrogant and other negative qualities. Treasure is purified of impurities in the process of acquiring, fulfilling the right of equalization and avoiding wasted storage. As for mustahiq, it can provide inner purity, away from jealousy and envy, pure from complaining with poverty and cultivating holiness to love one another.

There are three aspects to interpreting zakat, namely aspects of faith, economy and social. In the aspect of faith, zakat is a pillar of Islam that must be carried out, as a transidental relationship to Allah SWT. The Al-Qur'ān mentions approximately 82 verses that juxtapose zakat and șalāt simultaneously. ${ }^{7}$ Furthermore, in the aspect of social justice (al-'adālah alijtima $\bar{a}^{\prime}$ iyyah), namely to give birth to a system in achieving social and economic welfare in society. With mustahiq paying zakat, wealth does not only rotate among the rich, but spreads to the poor. The income of the poor increases, the economy grows at the individual and social level. ${ }^{8}$ The indicator of success is when mustahiq have switched their status to muzakki.

It was recorded that Indonesia's poor population, mid March 2019, released by the Central Statistics Agency amounted to 25.14 million people. ${ }^{9}$ There are still problems, because on one hand $9.4 \%$ of the population is in the poverty line, on the other hand, the payer is only about $3 \%$ of the total p. 169

${ }^{4}$ Firdaus, Kepemimpinan Khalifah Umar Ibn Abdul Aziz, Pedoman Ilmu, Jakarta, 1988,

${ }^{5}$ Kholik, Jamaluddin Achmad, Hukum Menginvestasikan Zakat dan Urgensinya Sebagai Instrumen Distribusi Kesejahteraan, (Jurnal Universum, 2016), p. 139

${ }^{6}$ Hafidhuddin, Didin, Membangkitkan Nilai-Nilai Zakat untuk Menyadarkan Umat, FOZ, Dompet Dhuafa Pemerintah Kota Padang, Jakarta, 2008, p. 12

7 Al-Ba'iy, 'Abdul Al-Hamīd Mahmūd, Ekonomi Zakat Sebuah Kajian Moneter dan Keuangan Syari'ah, Raja Grafindo Persada, Jakarta, 2006, p. 16

${ }^{8}$ Nuruddin, Muhammad Ali, Zakat Sebagai Instrumen dalam Kebijakan Fiskal, Rajawali Press, Jakarta, 2006, p. 1-2

${ }^{9}$ https://www.bps.go.id, Badan Pusat Statistik, Accessed, 15 of August 2020 
amount of 217 trillion rupiah of potential zakat payers, as stated by the Minister of National Development Planning, Head of Bappenas., (volume I), Bambang Brodjonegoro. ${ }^{10}$

Poverty alleviation is a shared responsibility, both Islam commands the State. As al-Qur'ān surah at-Taubah[9]: 103 states: "Take zakat from their property, to cleanse and purify them, and pray for them. Surely your prayer (brings) peace of mind for them. Allah is All-Hearing, All-Knowing". So important is the obligation of zakat, Caliph Abu Bakr once said: "By Allah, if they rebel against me, do not want to pay their camel zakat which they usually pay to Rasululallah SAW., Then I will really fight them because of their defiance". Then there was a riddah war, namely a war against those who were reluctant to pay zakat. ${ }^{11}$ This explains that zakat is a part of religion, fulfilling it is as obligatory as the other four pillars of Islam. Its theological function is to achieve the pleasure of Allah SWT, while its humanist function is to maintain good human relations by alleviating poverty.

In accordance with the 1945 Constitution, Article 34 mandates as described in the following paragraphs: (1) The poor and neglected children are cared for by the State. Paragraph (2) The state develops a social security system for all the people and empowers the weak and underprivileged in accordance with human dignity. (3) The state is responsible for the provision of adequate health service facilities and public service facilities.

To solve the problem of poverty, it is necessary to optimize the obligation to pay zakat as part of the pillars of Islam. Zakat collected, by the Amil Zakat Agency (AZA) is then invested in the productive business sector, so that it develops more and gets more profit. The results or profits from business investment are distributed as social security for the poor.

\section{Problems}

From the description of the background of the problem above, the authors are interested in raising the problems studied in this study, First, Can zakat assets be invested in productive enterprises ? Second, What is the mechanism for the form of social security from invested zakat assets?

\section{Research Methods}

This research is a sociological legal research, which sees law as an empirical social phenomenon. This research is to reveal the problems that lie

\footnotetext{
10 https: / /www.rri.co.id, Accessed, 15 of August 2020

11 ad-Damsyiqī, Abī al-Fidā' Ismā'̄̄l Ibn 'Umar Ibn Kasiīr al-Quraisȳ̄, Tafsīr al-Qur'ān al-
} 'Aẓīm, Dār Ibn Hazm, Beirut, 2000, p. 102 
behind the implementation and enforcement of the law. ${ }^{12}$ This research is a normative study by conducting library research or secondary data. The nature of this research is a descriptive study which aims to completely describe the characteristics of a situation, personal behavior and group behavior, and to determine the frequency of a symptom. ${ }^{13}$

The data used in this sociological legal research (socio-legal research) is secondary data and is strengthened by primary data or field data. The main secondary data are: UUD R.I. 1945, Article 34, UU. R.I. No. 23 of 2011, on Zakat Management, UU. R.I. No. 40 of 2004, concerning the Indonesian National Social Security System, al-Qur'ān and al-Hadīth on Zakat.

\section{Result and Discussion}

Zakat does not only alleviate poverty, but more than that as a distribution of wealth. So that the Mustahiqqun (people who are entitled to receive zakat) change their status to Muzakki (people who are obliged to pay zakat). When looking at this function, it is appropriate to position zakat as part of individual (religious) obligations as well as social obligations. The religious obligation is fulfilled by paying zakat from assets that have reached the minimum obligation to pay zakat. Meanwhile, the social obligation, zakat is managed by the management institution by following the provisions stipulated by the Government in the form of laws to be distributed to eight groups (așnāf), as stated in the Qur'an Surat at-Taubah [9]: 60; Fakir (Fuqarā '), Poors (Masākīn), Zakat manager ('Ämilīn), Mu'allaf, Servant (ar-Riqāb), People in debt (Gārimīn), People who strive in the way of Allah (fī sabīlillāh), People on the way ( Ibn sabīl). ${ }^{14}$

\section{The Purpose of Zakat in the Perspective of Law and Religion}

The Indonesian government has issued a special law on zakat management. From 1999 to 2020 there have been two revisions, namely Law No. 38 of 1999, regarding Zakat Management, replaced by Law No. 23 of 2011, regarding Zakat Management.

The law states that in managing zakat, the government forms an institution that specifically handles zakat management, namely the National Zakat Agency, with its main function is the national zakat management. The

12 Amiruddin dan H. Zainal Asikin, Pengantar Metode Penelitian Hukum, PT. Raja Grafindo, Jakarta, 2004, p. 133-134

${ }^{13}$ Soekanto, Soerjono, Pengantar Penelitian Hukum, UI Press, Jakarta,1982, p. 49, 53 \& 96

${ }^{14}$ Dāud, Anas Ismāīl Abu, Ensiklopedia Dakwah (Dalīlu as-Sāilīn) Penerjemah: Munirul Abidin dan Fuad Efendi, Malang Al-Qayyim, Malang, 2005, p. 647 
National Amil Zakat Board in the implementation of management, as its center is in the capital city of Jakarta, and the rest is at the Provincial and Regency/City levels throughout Indonesia. Each BAZNAS institution, both at the provincial and district/city levels, forms an organization called the Zakat Collection Unit (ZCU) to help collect zakat.

Article 3 of Law Number 11 Year 2011 states that zakat management aims to: (a) increase the effectiveness and efficiency of services in managing zakat; and (b) increasing the benefits of zakat to achieve social welfare and poverty alleviation. In Article 3 zakat allowance is the welfare of society and alleviating poverty. This means that the real function of zakat is to eliminate poverty.

Furthermore, in the explanation sheet, Chapter I General, paragraph six states: "Zakat must be distributed to mustahik in accordance with Islamic law. Distribution is carried out based on a priority scale by taking into account the principles of equity, justice and territoriality. Zakat can be utilized for productive efforts in the context of handling the poor and improving the quality of the people if the basic needs of mustahik have been met".

In interpreting the explanation above, that the management of zakat from its various aspects refers to Islamic syari'ah, which is sourced from the al-Qur'ān and al-Hadīth. Primarily in terms of distribution, it refers to the Qur'ān surah at-Taubah[9]: 60, with priority recipients who are in the respective Provinces, Regencies and Cities. Furthermore, it is stated in the issue of equal distribution and poverty alleviation, zakat can be empowered for productive endeavors, both at national, provincial and district and city levels.

Islam requires zakat as part of the pillars of Islam which is compulsory to be fulfilled, both from zakat on staple foods (fitrah), and zakat on assets ( $m \bar{a} l$ ). Its main purpose is servitude (ta'abbud) to Allah. So people who do not pay zakat are not legally valid. ${ }^{15}$ Because it is the pillar of Islam, the part that must be carried out.

Furthermore, zakat can be defined as assets which have been determined and partially issued when they meet the requirements, to be distributed to certain groups as determined by religion. Munawir said that "zakat is the taking of a portion of the property from Muslims for the welfare of Muslims and by Muslims". ${ }^{16}$

\footnotetext{
${ }^{15}$ Qarḍ̄̄īi, Yusuf, Fiqh az-Zakāt (Hukum Zakat) Diterjemahkan oleh: Salman Harun, Muassasah ar-Risālah, Beirut, 1973, p. 3

${ }^{16}$ Sadzali, Munawir, Zakat dan Pajak, Bina Rena Perwira, Jakarta, 1991, p. 160.
} 
On the other hand, zakat serves humanity. As Rasulullah Muhammad SAW once sent Mu' àd bin Jabal to Yemen:

Narrated from 'Abdullah Ibn Abbās R.A. that the Prophet SAW. sent Mu'ād bin Jabal to Yemen. His message to Mu'ād bin Jabal: "Call them to testify, that there is no God but Allah and I am the Messenger of Allah. If they obey this, then tell them that Allah obliged them to salät five times each day and night. If they obey it, then tell them that Allah obliges zakat to those who are collected from those who are rich to be distributed to those who are poor". (Bukhari Hadith History) ${ }^{17}$

By setting aside a portion of the property to be distributed to people less can be proof of devotion to the Creator and binding human relations, especially between the rich and the poor, giving each other moral and material benefits, between muzakki (giver) and mustahiq (recipient). ${ }^{18}$

If zakat is paid and distributed properly, it will not only solve the problem of poverty, but the positive impact will be able to foster morality values for both parties. In fact, zakat is a form of mutual cooperation between wealthy and dhu'afa $\bar{a}$, as a protection for society from poverty, physical and mental weakness, so that people who are preserved from disasters become people who live (thrive) and develop. ${ }^{19}$

From the description above, it can be concluded between the purpose of zakat from the law and syari'ah, as follows:

a. Meet the needs of groups of people in need (basic life), such as; an orphan who has no wealth and does not have a guardian to fulfill his living. Helping the poor, easing the burden of those in debt (the interests of the main needs and in the way of Allah), liberating my slave.

b. By giving from muzakki, it can clean up heart disease (mental) such as stingy and greed while for mustahiq it cleanses envy and envy, creates empathy.

c. Zakat for the development of the welfare of the ummah, as an instrument of equitable distribution of community income. Indonesia with the majority of the population is Muslim (86\%), most of whom are still in the mustahiq position, so that to build mosques, people still raise their hands on the streets to ask for donations. Including compensation for orphans, construction of religious schools, and so on.

${ }^{17}$ Az-Zabidi, Imam, Ringkasan Hadis Shahih al-Bukhari, Pustaka Amani, Jakarta, 2002, p. 328

${ }^{18}$ Qadir, Abdurrahman, Zakat dalam Dimensi Mazhab dan Sosial, Raja Grafindo Persada, Jakarta, 2001, p. 62-63

${ }^{19}$ Ash-Shidiqie, Teungku Muhammad Hasbi, Pedoman Zakat, PT. Pustaka Rizki Putra, Semarang, 1999, p. 8-9 


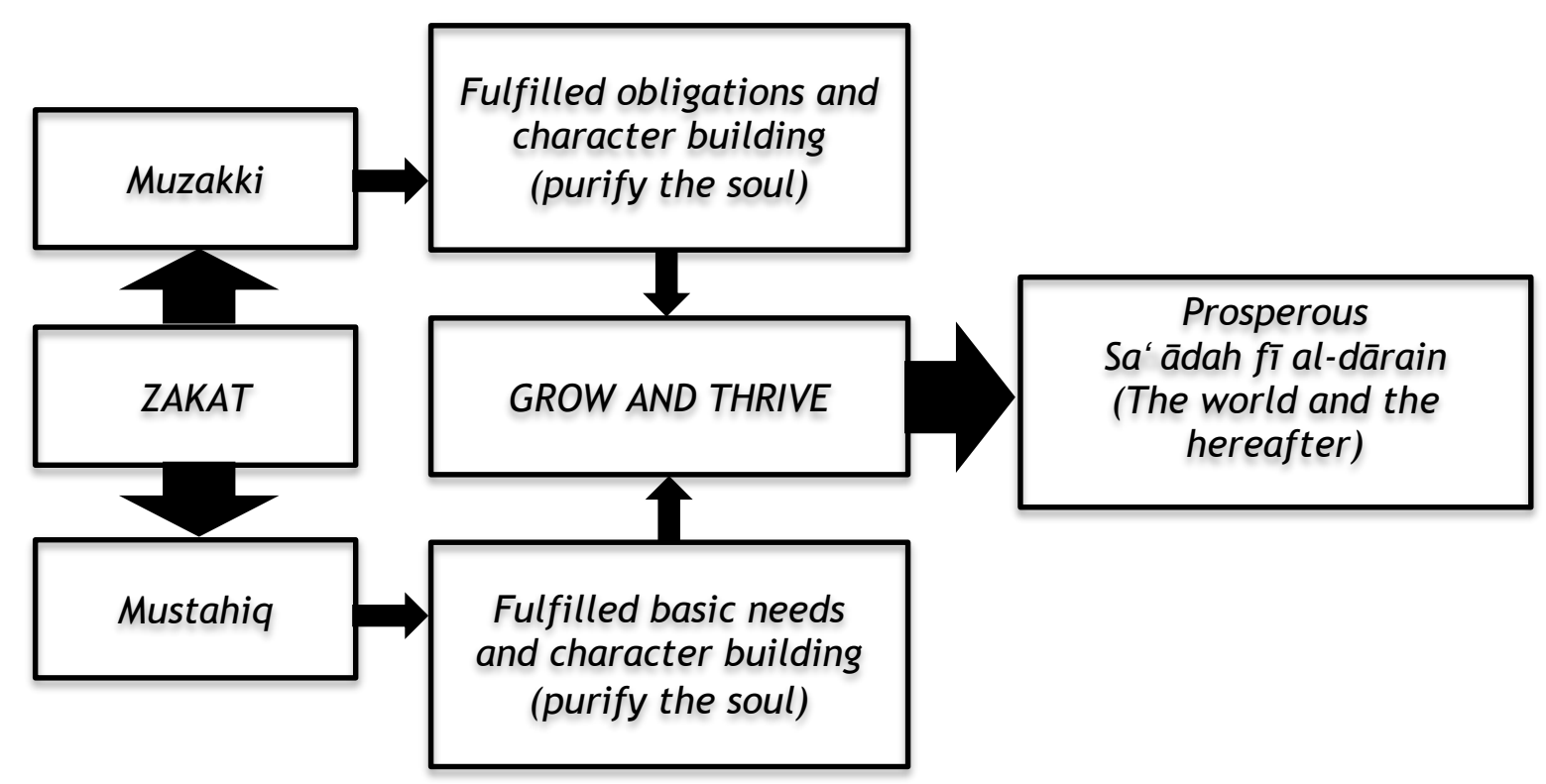

Figure 1.1. The Purpose of Obliging Zakat

The picture above shows the flow of zakat goals, both for muzakki (zakat payers) and mustahiq (zakat recipients). Zakat paid in a philosophical way has an impact physically and psychologically, spiritually and materially. By giving zakat, muzakki have fulfilled Allah's orders, religiously free from sin. If done voluntarily, sincerity and obedience are free from being stingy, greedy, greedy, and so on. While the zakat for the recipient (mustahiq) is physically fulfilled by their basic needs. By fulfilling the basic needs of life, psychologically giving birth to a sense of love, and avoiding jealousy and envy towards rich people.

With zakat, awareness grows for the rich to give, while for the poor, a sense of love grows. This is the essence of growth, on the one hand there is a flow of distribution of assets, on the other hand it closes the loopholes for criminal action that creates security. It could be that, with zakat which is used as a productive business (either directly by mustahiq) or by zakat institutions, it will also develop zakat assets. The ultimate goal of zakat obligation and proper management is welfare. Welfare has carried out its obligations as mukallaf (people who have been obliged to carry out religious orders), have also fulfilled the basic needs of life, and have increased to become people who like to share, to the point that it is difficult to find people who want to receive zakat assets. Falah or happiness is not only in this world, but also continues until eternal life (the afterlife). 


\section{Overview of Zakat Property Investment}

Investment in Arabic is called "istismār" which means "taự̄if al-māl", namely investment. ${ }^{20}$ It can also be interpreted as to achieve profit "talab alhușūl "alā al-samri", which is an increase in wealth from before. ${ }^{21}$ It is also called "istismāriyah" that is, "to produce something from something" or "to make something bear fruit and bear something" because it comes from "samar" or "samr" which means fruit. If it is associated with zakat assets it means:

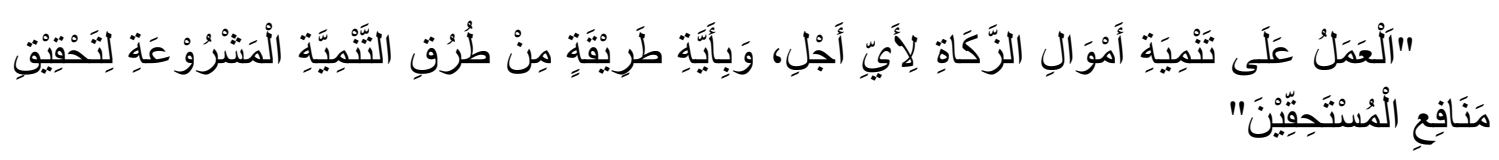

"The effort to develop zakat assets is due to a reason and a way of developing the means to realize the benefits (for) of the mustahiq (beneficiaries of zakat)". 22

Investment is an activity to attract sources of funds used for providing capital goods, and capital goods will produce new products. (Sutrisno 2008) Kamaruddin Ahmad, in Abdul Manan said, ${ }^{23}$ that what is meant by investment is placing money or funds in the hope of obtaining additional or certain benefits on the money or funds. In this definition, investment is focused on placing money or funds with the aim of obtaining the expected profit.

It can be understood, that zakat investment is the process of developing zakat assets with various business approaches so that the principal of assets and the value of their benefits increase. With the increase in the nominal value of zakat assets, the greater the distribution value and usefulness for the mustahiq.

There are several verses related to investment, among them are the Qur-ān surah al-Nisā'[4]: 9:

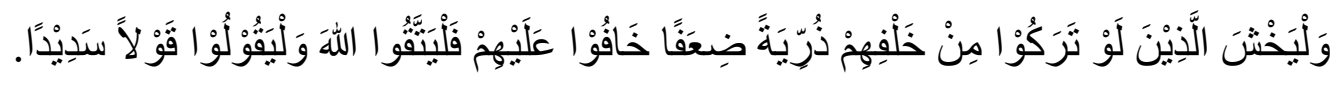

20 Ali, Atabik, Kamus "Krapyak" al-Ashri Arab-Indonesia, Multi Karya Grafika, Yogyakarta, 2003, p. 93

${ }^{21}$ Ahmad, Qasim Haji, Istiśmā Amwāl al-Zakāh wa Dauruhu fī Tahqīqi al-Filiyyah alIqtișādiyyah, al-Markaz al-Jami', Lubnan t.t., p. 3-4

${ }^{22}$ Syabīr, Muhammad 'Uṡmān, Istiṡmāru Amwāli al-Zakāh, Ru'yatu Fiqhiyyah Mu'āșirah Bahśu Damn Mawaụ wa 'Āt al-Nadwah al-S̄ālišah li Qaḍāyā al-Zakāh, al-Mu'āṣirah, Kuwait, 1992, p. 506

${ }^{23}$ Manan, Abdul, Hukum Ekonomi Syariah dalam Prespektif Kewenangan Peradilan Agama, Kencana Prenada Group, Jakarta, 2012, p. 149-150 
"And fear Allah those who should leave behind them weak children, whom they worry about (their welfare). Therefore, let them fear Allah and let them speak the right word. ${ }^{24}$

The verse can be interpreted, so that everyone will feel worried if the future leaves behind a weak generation (żurriyatan $d u^{\prime} a f \bar{a}^{\prime}$ ). Can be weak because of financial, which has a big impact on weak faith (käda al-faqru an yakūna kufran) "poverty is more likely to lead to kufr".

So to get the blessing and sanctity of property as a fundamental characteristic of zakat, investment must be channeled to halal businesses and minimal risk. Should not be channeled into illegal and high-risk businesses. Like two sides of a coin, ribh (profit) and fāșil (loss) in investing is always there. Profits as one factor motivates investors to invest, as well as benefits in assuming the risk of the investment carried out. ${ }^{25}$

In the legal spotlight on the investment of zakat assets there are differences, some do not allow and others allow. Among the fuqahä' who did not allow it were Wahbah al-Zuhaily, Shaykh 'Abdullah' Ulwan. Shaykh Muhammad Taqi al-'Usmāny and Sheikh Muhammad ' Ațā al-Sayyid. Meanwhile, one of the fatwa institutions that prohibits this practice is al-Lajnah alDāimah Lil-Buhūs̀ al-' Ilmiyah wa al-Iftā', Saudi Arabia, for reasons; (1) Not in accordance with the provisions set by naș (al-Qur'ān and al-Hadīth), (2) Zakat assets must be distributed as soon as possible to those who are entitled, should not be postponed so that it is obligatory, (3) Contrary to the spirit of the value of worship, so that it has the potential to change the values of faith into a business, such as zakat on agriculture and livestock to be replaced with money for business capital, (4) Inhibiting the ownership of the benefits of zakat for individuals, while zakat is actually intended to be fully owned by the recipient of zakat (mustahiq). ${ }^{26}$

Groups that allow the investment of zakat assets, among them are Sheikh Yusuf al-Qarḍawī, Sheikh Muștafā al-Zarqā', Sheikh 'Abdul Fattaāh Abu Gadah, Sheikh 'Abdul 'Azīz al-Khayātt, and Sheikh 'Abdus Salām al-Abadī. ${ }^{27}$ Among the institutions that allow it are the Mujamma Fatwa Institute Fiqh alIslāmy, the Lajnah al-Fatwa of the Kuwaiti Ministry of Waqf, and the 2003

${ }^{24}$ Prasetyoningrum, Ari Kristin, Risiko Bank Syari'ah, Pustaka Pelajar, Yogyakarta, 2015, p. 31

${ }^{25}$ Halim, Abdul, Analisis Investasi, Salemba Empat, Depok, 2003, p. 38

${ }^{26}$ Ahmad, Qasim Haji, Ibid.

${ }^{27}$ Șabir, Muhammad 'Uṡmān, Istišmāru Amāl al-Zakāh Ru'yah Fiqhiyyah Mu'āșirah, Dār al-Nafāis, Aman, 2004, p. 516 
Fatwa Majlis Ulama Indonesia (MUI). The reasons for allowing investment include the following:

First, Rasulullah SAW and Sahabat Umar once took advantage of zakat assets, before being distributed to recipients. As the hadith of the Prophet SAW. From Zaid bin Aslām he said: "Umar bin Khațāa drank milk which made him amazed". Then he asked the person who gave the drink, "where did you bring this milk from?" The person told that he had come to a spring-which he mentioned his name-in fact he got a number of camels from the camels of alms (zakat), they were giving his cattle drink, then they milked it for me, then I brought it to my drinking container. this! Then Umar put his hand, then drank it. ${ }^{28}$

Second, based on āisaru al-șahābah (actions of friends) established by Amīrul Mukminīn 'Umar Ibn al-Khaț̣āb R.A. which prohibits letting the property of the orphaned children not invested, so that they are consumed by alms. If the assets (mandate) of orphans can be used as business capital (investment), especially zakat assets which benefit mustahiq.

Third, a leader has the right to hold and distribute zakat based on the value of benefit. As did the Caliph 'Umar Ibn al-Khaț̣āb R.A. function of Bait al-Māl (state treasury) to give mu'allaf (stop giving zakat) and pay the soldiers as a substitute for the distribution of fa'i assets.

Rasulullah said, "It is better for you than to come begging to be a black stain on your face on the Day of Judgment. Because actually begging is not proper except for three groups: for very faqīr people, for those who are in debt who are unable to pay, or for those who have blood (diyat debt) that troubles them ". ${ }^{29}$

That the workers/managers (ämilinn) of zakat are based on the authority of the leader (imām), then they set policies based on the greater benefit. As the rule; "Tașarrufu al-imām 'alā al-ra'iyyati manūțun bi al-mașlahah". "Government policy towards the people is based on benefit (benefit)". ${ }^{30}$

Yusuf Qardawi stated in Fiqh Zakat, that the Islamic government is allowed to build factories or companies from zakat money for ownership and profits for the poor, so that their daily needs will be fulfilled. ${ }^{31}$

${ }^{28}$ Anas, Mālik Ibn, Al-Muwaț̣a, Mansyurat al-Mujamma' al-śaqafī, Abu Dabi, 2004, p.

${ }^{29}$ al-Sijistan̄̄, al-Imām Abu Dawud, Sunan Abu Dawud, al-Maktabah al-Mișriyyah, Beirut t.t., p. 126

${ }^{30}$ al-Suyuțī, Jalāluddīn bin 'Abdurrahmān, al-Asybāh wa al-Nażār, Dār al-Fikr, Beirut, 2011, p. 158

${ }^{31}$ Qardawi, Yusuf, Fiqh Zakat, Juz II, Muassasah Risalah, Beirut, 1991, p. 567 
Based on the description above, zakat can be invested with the following conditions mentioned by the Indonesian Ulema Council (IUC): (1) It must be distributed to businesses justified by shari'ah and applicable regulations (al-țuruq al-masyru'ah). (2) Invested in business fields that are believed to provide benefits based on feasibility studies. (3) Fostered and supervised by competent parties. (4) Conducted by an institution or institution that is professional and trustworthy (trustworthy). (5) An investment permit (istismār) must be obtained from the government and the Government must replace it in the event of a loss or bankruptcy. (6) There are no needy people who starve or need expenses that cannot be postponed when zakat assets are invested. (7) The distribution of zakat that ended because it is invested must be limited in time. ${ }^{32}$

The mechanism of the Zakat Management Agency (ZMA) in managing zakat assets through investment can be, first; directly, namely involved in capital and ownership, either in whole or in part and may be involved in the management of its operations. Such a contract is called a syirkah. Second, indirectly. Through Mudārabah, the Zakat Management Agency (ZMA), provides full capital as an investor (șāhibul māl), the business is run by the party invited to cooperate. In addition, the owner of the capital is not involved in business management. As for the profit, it is divided according to the nișbah (share) agreed by both parties. 33

In terms of investing zakat assets, it is possible that the manager ('ämilīn 'alaih) of zakat, muzakki (giver) and mustahiq (recipient) invested. However, according to the author's opinion, it is sufficient for the Zakat Management Agency (ZMA) with government guarantees to carry out productive efforts on zakat assets so that they are more measurable and have greater value for their benefits, both in terms of capital (collected) and the results of the business in question. It could also be a system of giving property directly to the poor with a system of businesses as family food security with assistance and standard operating procedures for implementation of the Zakat Management Agency (ZMA).

For a clearer flow of zakat investment, the figure below provides a systematic description.

${ }^{32}$ Amin, Ma'ruf, Fatwa Majlis Ulama Indonesia Nomor 4 Tahun 2003 Tentang Penggunaan Dana Zakat Untuk Istitsmar (Investasi), MUI, Jakarta, 2003, p. 6

${ }^{33}$ Mardani, Hukum Ekonomi Syari'ah di Indonesia, PT Refika Aditama, Bandung, 2011, p. 


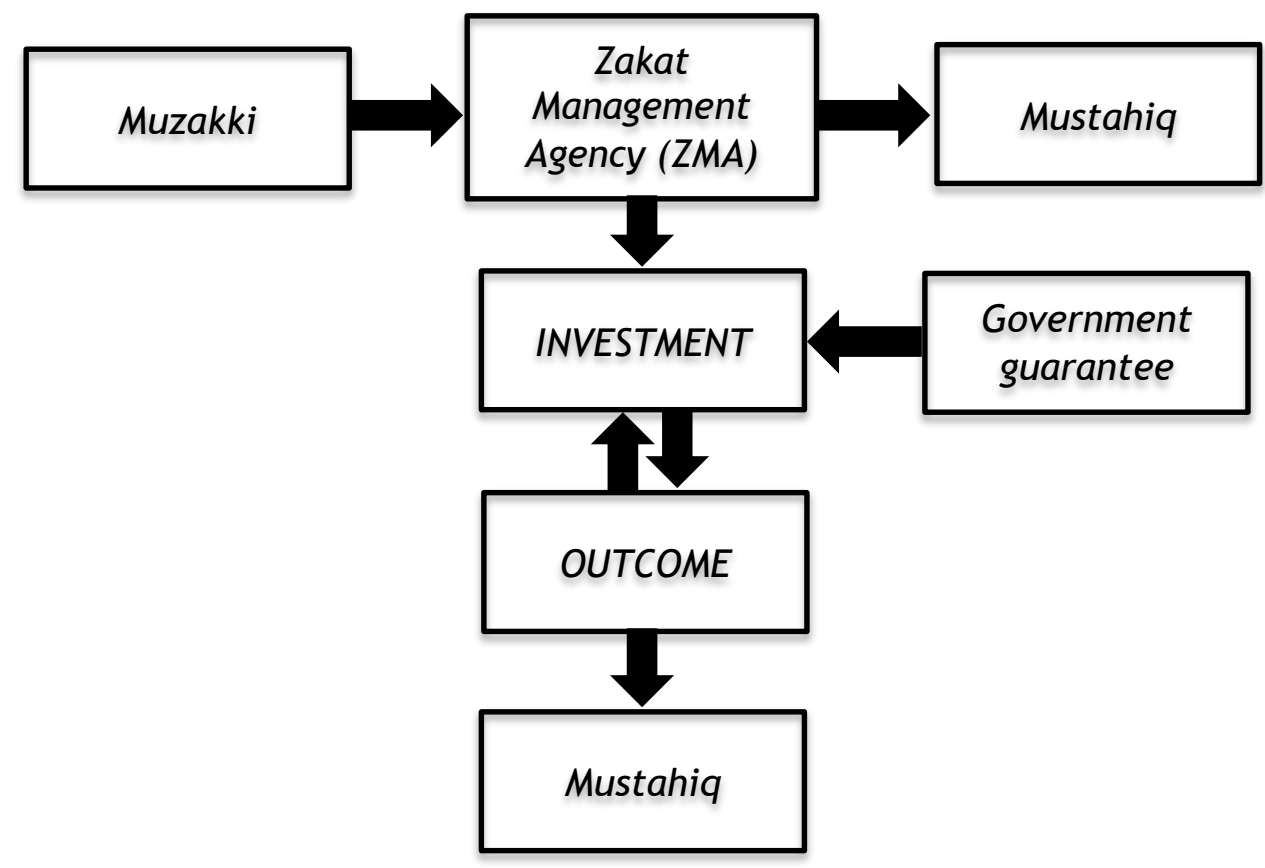

Figure 2.1. Flow of Utilization of Zakat Assets for Investment

The plot image explains: (1) Muzakki pays the obligation of zakat to the Zakat Management Agency (ZMA) (2) The Zakat Management Agency (ZMA) then distributes it in two ways, directly for mustahik for the very urgent basic needs of life. The distribution of zakat assets is suspended, diverted to be invested or developed. (3) Zakat assets by ZMA are invested in businesses with minimal risk and quick profit, such as in the nine staple goods sectors of the community. It is possible for the government to make regulations to close import faucets and seek the procurement of its needs from the UmmahOwned Zakat Business Entity (UOZBE). (4) In investing by the Zakat Management Agency (ZMA), in this case the government is obliged to provide a loss guarantee, if in the future the business being run experiences bankruptcy (loss). The government took the initiative to make a Special Business Entity owned by Zakat. (5) Part of the proceeds from productive zakat (investment) is distributed to mustahiqīn, while the other part is used for business development again. The percentage of proceeds to be developed and distributed to those who are entitled to receive benefits from the investment of zakat assets based on the ijtihād (consensus) of the 'amilīn (zakat workers).

In terms of productive business, the authors are more likely to direct the sector to nine staple goods, abbreviated as "groceries", which clearly have a market and the government has the power to suppress imports of these necessities of life. It could also be in strategic sectors, such as agriculture, 
fisheries and plantations as the largest producers of the said staples. In terms of function, the government takes direct responsibility for these goods not to let their prices run wild to the tastes of the market. If you follow the market, there can be a very high spike, or a very sharp decline, it will cause misery for the people. The Ministry of Trade of the Republic of Indonesia explained ${ }^{34}$ that including nine basic goods are; (1) rice (2) sugar (3) cooking oil and butter (4) beef and chicken (5) chicken eggs (6) milk (7) corn (8) kerosene (9) iodized salt.

The function of zakat as equity and community development can be seen when it can minimize the circulation of money only to the rich. So with the natural resources owned by Indonesia, food needs must be cultivated by yourself, not importing. This is where the synergy of the government carries out the function of zakat as income distribution and community development by building business entities in the food security sector. The National Statistics Agency recorded the largest foodstuff imports for the JanuaryNovember 2018 period (1) wheat and meslin 9.2 million tons (2) sugar 4.6 million tons (3) salt 2.5 million tons (4) soybeans 2.4 million tonnes, and (5) rice 2.2 million tonnes. (National Statistics Agency 2019). The following is a picture of import statistics for several food commodities of the Republic of Indonesia in the middle of January-November 2018.

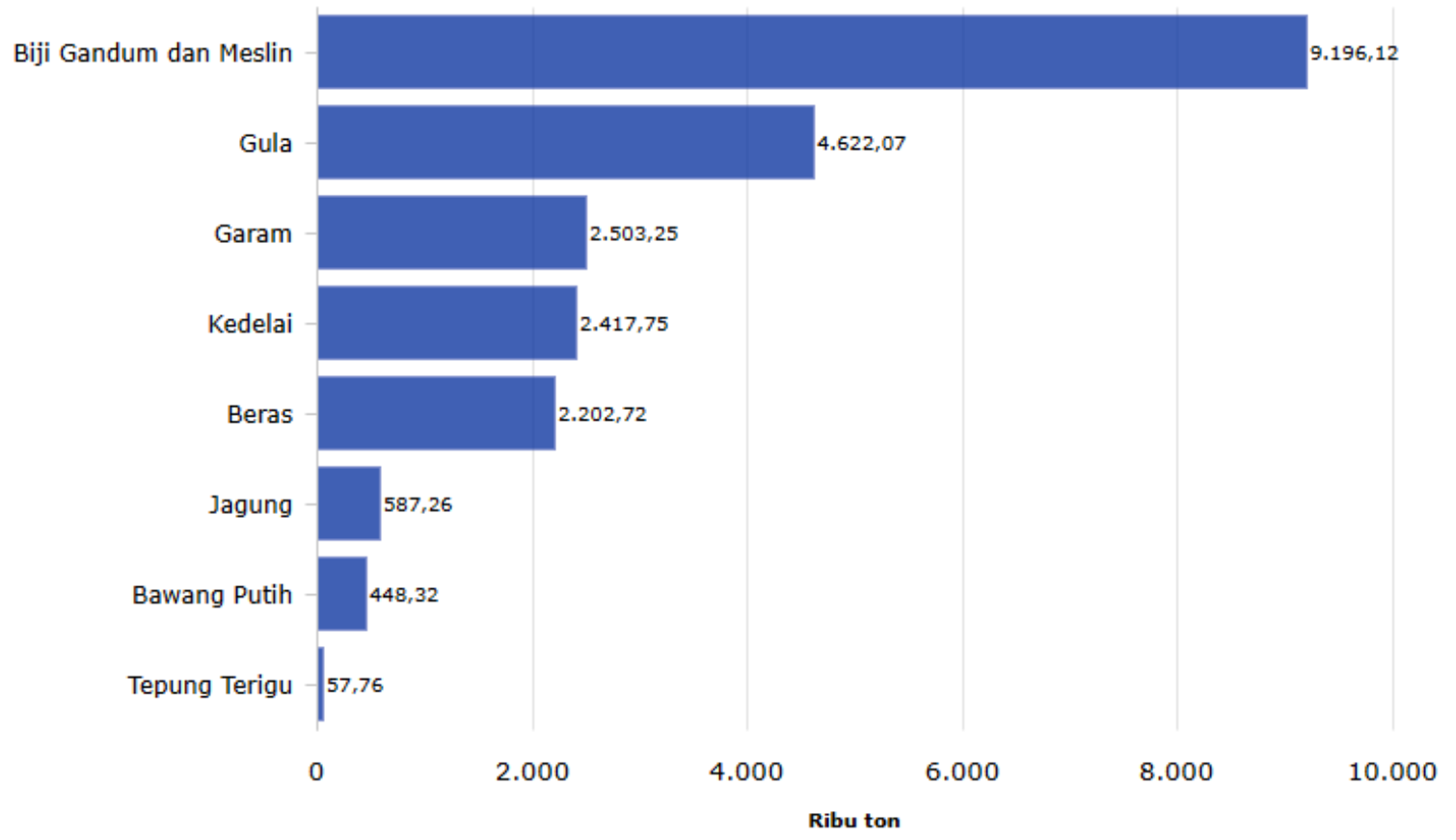

Figure 2.2. Imports of Several Food Commodities (January-November 2018)

34 Decree of The Minister of Industry and Trade, Number. 115/MPP/KEP/2/1998, Jakarta, 27 Februari 1998 
The Zakat Management Agency (ZMA) can also distribute zakat to mustahiq by forming community groups (colonies) through family food security programs. ZMA prepares programs for the poor with Standard Operating Procedures (SOP) that must be implemented. The main obstacle for the poor is minimal land, so that the harvest is not enough to meet their needs. For this reason, in resolving these problems, it can be made in groups by acquiring land from ZMA. In the modern era like today, it could also be a farming estate system (agricultural housing) with an area of 1,000 $\mathrm{M}^{2}$ to 2,000 $M^{2}$.

In this program, the work plan must be clear. Starting from preparation to sales. Every mustahiq is educated to be able to manage narrow land with multipurpose. From the results of the business, it can be used as a fulfillment of life's needs, as savings (livestock), in installments for the revolving funds to ZMA and the goal is to become muzakki. The following is an overview of the program in question.

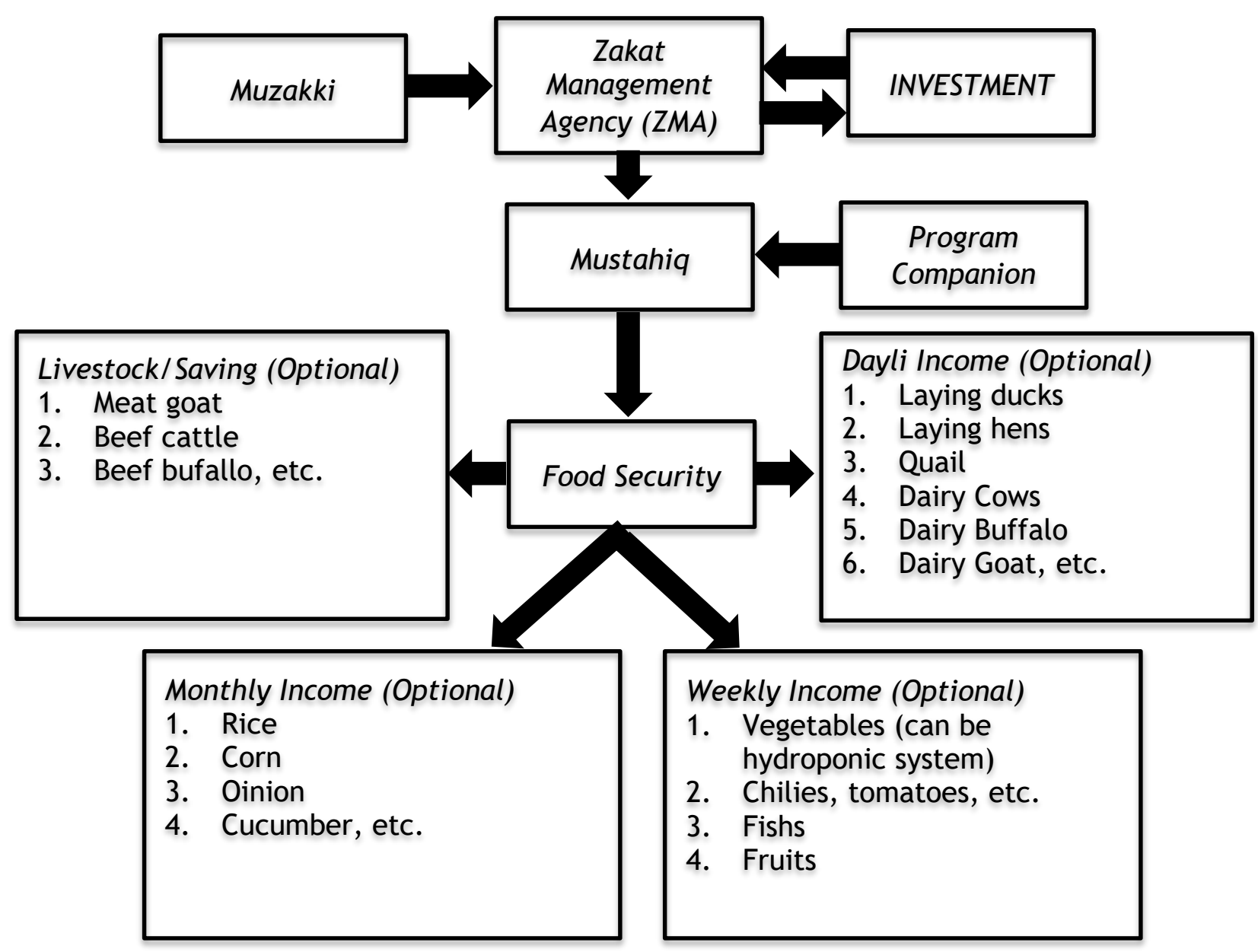

Figure 2.3. Distribution of Zakat on Investments to Mustahiq (Food Security Assistance System) 
The explanation of the picture above is as follows: (1) The source of zakat assets comes from muzakki and the proceeds from the investment of zakat assets. (2) The Zakat Management Agency (ZMA) distributes by forming business groups (zakat beneficiaries) with family food security business programs. (3) In the process of business activities, there are professional assistants for both business activities and digital marketing of business results. (4) Mustahiq carry out business activities that can be harvested daily, weekly, monthly and yearly.

For example, mustahiq raises 18 laying ducks and 2 males, grows chilies, vegetables, rice, raises catfish and raises four female and one male goats. To meet daily needs, protein from duck eggs, fruit from papaya. In addition, you can also eat once a week with fish as a side dish. For reserves that can be used as savings in the form of goats, buffalo or cows. Goats (sheep) that can breed from four females for six months have added four puppies. The next six months add four. In one year they can sell three goats as savings, and will continue to grow if it is carried out seriously and organized.

\section{Investment of Zakat Assets as Social Security}

Social security according to the International Labor Organization (ILO) is also called social security, is a system of protection provided by the community for its citizens, through various efforts to face economic or social risks that may result in the cessation of or greatly reduced income. ${ }^{35}$ Meanwhile in Law no. 40 of 2004, concerning the National Social Security System, that what is meant by social security is; "A form of social protection to ensure that all people can fulfill their basic needs for a decent life". ${ }^{36}$

Still in the law, it limits that the types of social security programs include: a) health insurance; b) work accident insurance; c) old age security; d) pension benefits, and e) death benefits. The mechanism is based on the principle of mutual cooperation, each participant is required to pay a fee.

The term social security in Islamic scientific literacy refers to three terms, namely takâful al-ijtimā' $\bar{\imath}$, damān al-ijtima $\bar{a}^{\prime} \bar{\imath}$ and ta'min al-ijtimáa $\bar{r}$.

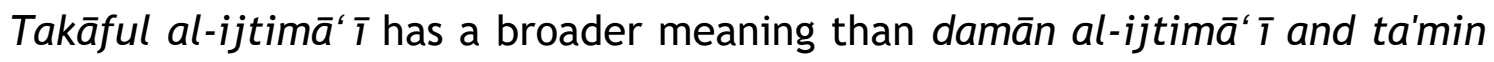
al-ijtim $\bar{a}^{\prime} \bar{i}$, the meaning of which is the collective responsibility of everyone in society for the difficulties and hardships of life that befall or experienced

${ }^{35}$ Lalu, Husni, Pengantar Hukum Ketenagakerjaan Indonesia, (Edisi Revisi), Rajawali Press, Jakarta, 2003, p. 53

${ }^{36}$ UU R.I. No. 40 Tahun 2004, tentang Sistem Jaminan Sosial Nasional, Bab 1 Ketentuan Umum, Pasal 1 ayat (1), 29 Oktober 2004 
by others in society, by providing assistance in the form of financial (financial) and moral. So takâful al-ijtimā $\bar{a}^{\prime} \bar{T}$ is also called social interpendence or social solidarity. ${ }^{37}$

Damān al-ijtimá' $\bar{\imath}$ means the obligation of the government to guarantee the community's difficulties and difficulties by providing assistance as a very basic provision of life. This is the essence of what is called social security in the view of western scholars.

While the term ta'min al-ijtima' $\bar{i}$ which is also known as social insurance, is only as one principle among several principles in order to achieve damān al-ijtimā' $\bar{r}$. Social insurance provides limited insurance to certain people, who become participants according to a contract and limited to certain events, as stated in the Law of the Republic of Indonesia Number 40 of 2004 concerning the National Social Security System.

When referring to the three terms, then the benefits of zakat as social security cover all three. It is more comprehensive in terms of its meaning and includes elements of society and government as well as in the practice of implementing its collection and distribution. In essence, in the Islamic view, social security is essentially the State's obligation to the people to guarantee their social life. So that in realizing prosperity, it cannot be separated from the role of society and government together. The government as a policy maker takes the obligation to pay zakat from those who can afford it and distributes social security. Syauqī al-Fanjarī said, that social security can be seen from two aspects. First, social security as the government's responsibility is in accordance with the meaning of damān al-ijtim $\bar{a}^{\prime} \bar{i}$ and second, as the responsibility of people who are sufficient (able to at least) to fulfill their obligation to pay zakat as in the meaning of takâful al-ijtimāa' $\bar{\imath}^{38}$

It can be said that zakat is the first social security law that does not rely on alms or voluntary community contributions. This law is enforced on government assistance to meet the needs of each individual for his basic needs, at least clothing, food and shelter. This applies to a person personally and all their dependents without excess waste and savings. This applies not only to Muslims, but to those who live under the auspices of the Islamic State of various religions and beliefs. ${ }^{39}$

${ }^{37}$ Alfin, Aidil, Konsep Jaminan Sosial Dalam Sistem Ekonomi Islam (Analisis Terhadap Istilah Takāful al-Ijtimā'T, Damān al-Ijtimā'î dan Ta'min al-Ijtimā'̄î), Al-Huriyah, Vol. 12, No. 2, Juli-Desember, 2011, p. 25

${ }^{38}$ Al-Fanjarī, Muhammad Syauqī, al-Islām wa Damān al-Ijtimā'î, Dār Śaqīf li an-Nasyr wa al-Ta'līf, Riyāọ, 1986, p. 33

${ }^{39}$ Songgirin, Amin, Essay: Zakat Sebagai Investasi Usaha dalam Perspektif Islam, Institut Agama Islam Al-Aqidah, Jakarta, 2004, p. 62-63 
Zakat is a guarantee with a fixed source and place of distribution. This way, there will be no feeling of shame or humiliation among those who ask for help. Likewise, various civil rights of the poor who are often abused because their position as recipients of assistance can be maintained and maintained.

Social security as written in Q.S. at-Taubah [9]: 60 is reserved for certain groups, in various ways.

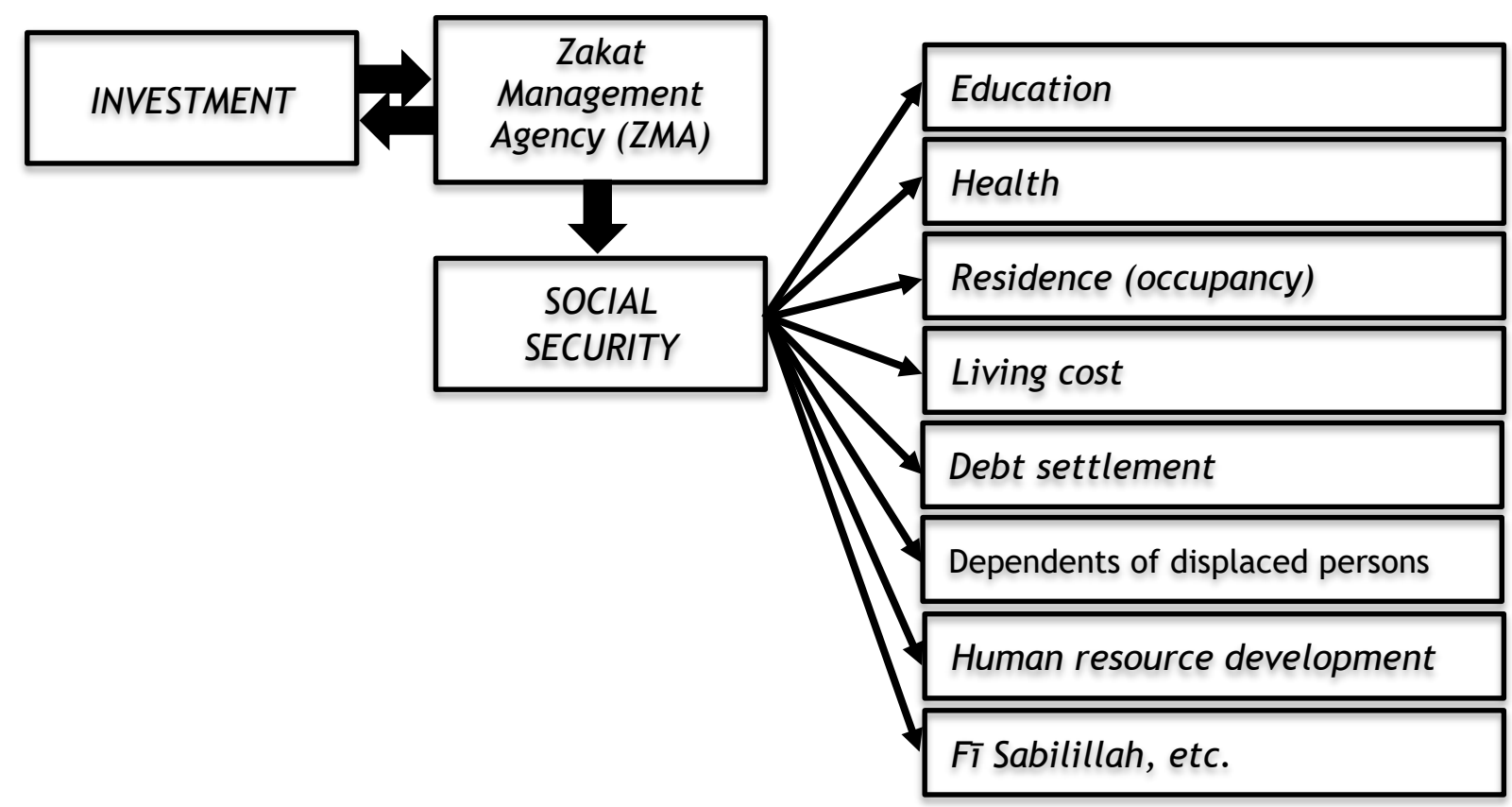

Figure 3.1. Investment of Zakat Assets as Social Security

In the picture above, it explains the benefits of zakat assets invested in productive businesses which function as social security for beneficiaries (mustahiq). Assets invested through a government-formed business entity, namely the Ummah-Owned Zakat Business Entity (UOZBE) under the management of the National Zakat Management Agency are distributed as social security for education, health, housing, living expenses, debt repayment (gārimīn), dependents for displaced people (including street children), human resources development, paying the Qur'an teachers (in community), building religious facilities and their supporters ( $f \bar{i}$ sabīlillah), etc.

In some practices, social security has been implemented by the National Zakat Management Agency such as BAZNAS (Badan Amil Zakat Nasional) by launching several Zakat Community Development (ZCD) programs, Mustahik Service Counters (MSC), BAZNAS Healthy Homes (BHH), 
Smart Home of the Nation's Children (SHNC), Baitul Qirad BAZNAS (BQB), Disaster Emergency Response Program, 1000 Ulama 'regeneration program. ${ }^{40}$

\section{Conclusion}

Zakat is mäliyah ijtima' iyyah worship, the pillars of the five pillars of Islam and fulfilling them is an obligation. Paying zakat as proof of religious obedience and carrying out human values in social life, because zakat assets contribute to building the socio-economic community.

In addition to giving zakat a positive impact on muzakki, cleansing the soul from all heinous deeds and heart disease also improves the quality of faith and gratitude to God. Zakat assets also have the function of cleaning property as well as developing, both for muzakki and mustahiq. For mustahiq, the benefits of zakat can provide space for rizki, keep away from hunger, reduce the burden of life necessities, keep away from despicable acts (by asking for or because of poverty), maintain religion and morals, motivate themselves to improve work ethics, so that later the status changes to muzakki. That is the essence of the meaning of growing, blessing, developing, holiness, and al-șalāh.

Investment of zakat assets is allowed in religion, even if we understand the meaning of zakat to achieve benefit (welfare), it is recommended. However, the investment of zakat property must be made on businesses that are not prohibited by the shari'ah and have certain benefits, not on haram and speculative businesses. The government plays an important role as a mover, supervisor and evaluator in the management of zakat investment and as a guarantor in the event of a loss in the zakat productive business. To get big profits, it is necessary to establish a national scale Ummah-Owned Zakat Business Entity (UOZBE). With abundant profits, socio-economic problems will be resolved, because all the increase in zakat assets is part of zakat that must be distributed to mustahiqs.

Zakat itself has a role and function as social security. One side is the obligation for the community to help each other, to work together to help the marginalized (social solidarity), on the other hand, the role of the government is to bear the basic cost of living for those who are at the level of not prosperous (social security).

The more zakat assets are managed properly and well, the more poverty will be reduced. The more integrity management of zakat assets, the function of zakat as social security will be realized.

40 Jaelani, Aan, Manajemen Zakat di Indonesia dan Brunei Darussalam, Nurjati Press, Cirebon, 2015, p. 88-96 


\section{Bibliography}

Abī al-Fidā' Ismā'̄̄l Ibn 'Umar Ibn Kas̀īr al-Quraisȳ̄ Ad-Damsyiqī, Tasīr alQur'ān al-'Až̄im, Dār Ibn Hazm, Beirut, 2000.

'Abdul Al-Hamīd Mahmūd Al-Ba'iy, Ekonomi Zakat Sebuah Kajian Moneter dan Keuangan Syari'ah, Raja Grafindo Persada, Jakarta, 2006.

Aidil Alfin. Konsep Jaminan Sosial Dalam Sistem Ekonomi Islam (Analisis Terhadap Istilah Takāful al-ljtimāî, Damān al-ljtimāî dan Ta'min alIjtimāīi). Al-Huriyah, Vol. 12, No. 2, Juli-Desember, 2011: 25.

Atabik Ali, Kamus "Krapyak" al-Ashri Arab - Indonesia, Multi Karya Grafika, Yogyakarta, 2003.

Al-Imām Abu Dawud Al-Sijistanī, Sunan Abu Dawud, al-Maktabah al-Miṣriyyah, Beirut, t.t.

Amiruddin dan H. Zainal Asikin,. Pengantar Metode Penelitian Hukum, PT. Raja Grafindo, Jakarta, 2004.

Anas Ismāīl Abu Dāud, Ensiklopedia Dakwah (Dalīlu as-Sāilīn) Penerjemah: Munirul Abidin dan Fuad Efendi, Al-Qayyim, Malang, 2005.

Ashima Faidati, Pendistribusian Zakat Perdagangan Telur Ayam Petelu: Studi Kasus Desa Punjul Kecamatan Karangrejo Kabupaten Tulungagung, IAIN Tulungagung, Tulungagung, t.t.

Aan Jaelani, Manajemen Zakat di Indonesia dan Brunei Darussalam, Nurjati Press, Cirebon, 2015.

Amin Songgirin, Skripsi: Zakat Sebagai Investasi Usaha dalam Perspektif Islam, Institut Agama Islam Al-Aqidah, Jakarta, 2004.

Ari Kristin Prasetyoningrum, Risiko Bank Syari'ah, Pustaka Pelajar, Yogyakarta, 2015.

Abdurrahman Qadir, Zakat dalam Dimensi Mazhab dan Sosial, Raja Grafindo Persada, Jakarta, 2001.

Abdul Manan, Hukum Ekonomi Syariah dalam Prespektif Kewenangan Peradilan Agama, Kencana Prenada Group, Jakarta, 2012.

Abdul Halim, Analisis Investasi, Salemba Empat, Depok, 2003.

Budi Salim dan Sutrisno, Hukum Investasi di Indonesia, Rajawali Press, Jakarta, 2008.

Badan Pusat Statistik Nasional. databoks. Februari 18, 2019. https: //databoks.katadata.co.id (accessed Agustus 24, 2020).

BPS Indonesia. Badan Pusat Statistik. Juli 15, 2019. https://www.bps.go.id (accessed Agustus 17, 2020).

Didin Hafidhuddin, Membangkitkan Nilai-Nilai Zakat untuk Menyadarkan Umat, FOZ, Dompet Dhuafa Pemerintah Kota Padang, Jakarta, 2008.

Firdaus, Kepemimpinan Khalifah Umar Ibn Abdul Aziz, Pedoman Ilmu, Jakarta, 1988. 
Husni Lalu, Pengantar Hukum Ketenagakerjaan Indonesia (Edisi Revisi), Rajawali Press, Jakarta, 2003.

Haji Ahmad Qasim, Istiśmār Amwāl al-Zakāh wa Dauruhu fī Tahqīqi alFi'liyyah al-Iqtișādiyyah, al-Markaz al-Jami', t.t.

Imam Az-Zabidi, Ringkasan Hadis Shahih al-Bukhari, Pustaka Amani, Jakarta, 2002.

Jamaluddin Achmad Kholik. Hukum Menginvestasikan Zakat dan Urgensinya Sebagai Instrumen Distribusi Kesejahteraan. Universum, 2016.

Jalāluddīn bin 'Abdurrahmān Al-Suyuțī, al-Asybāh wa al-Nażār, Dār al-Fikr, Beirut, 2011.

K Amirundin, Model-Model Pengelolaan Zakat di Dunia Muslim, UIN Sunan Ampel, Surabaya, t.t.

Kementerian Agama R.I., Modul Penyuluhan Zakat, Dirjen Bimas Islam, Direktorat Pendayagunaan Zakat, Jakarta, 2013.

Mālik Ibn Anas, Al-Muwața, Mansyurat al-Mujamma' al-śaqafī, Abu Dabi, 2004.

Mardani, Hukum Ekonomi Syari'ah di Indonesia, PT Refika Aditama, Bandung, 2011.

Muhammad Syauqī, al-Islām wa Damān al-ljtimā̄ị Al-Fanjarī, Dār Śaqīf li anNasyr wa al-Ta'līf, Riyāọ, 1986.

Ma'ruf Amin, Fatwa Majlis Ulama Indonesia Nomor 4 Tahun 2003 Tentang Penggunaan Dana Zakat Untuk Istitsmar (Investasi), Majlis Ulama' Indonesia (MUI), Jakarta, 2003.

Menteri Perindustrian dan Perdagangan. Keputusan Menteri Perindustrian dan Perdagangan No. 115/MPP/KEP/2/1998. Jakarta: Keputusan Menteri Perindustrian dan Perdagangan R.I., 27 Februari 1998.

Muhammad Ali Nuruddin, Zakat Sebagai Instrumen dalam Kebijakan Fiskal, Rajawali Press, Jakarta, 2006.

,Fiqh Zakat, Juz II, Muassasah Risalah, Beirut, 1991.

Munawir Sadzali, Zakat dan Pajak, Bina Rena Perwira, Jakarta, 1991

Muhammad 'Uṡmān Syabīr, Istiṡmāru Amāl al-Zakāh Ru'yah Fiqhiyyah Mu'āșirah, Dār al-Nafāis, 'Aman, 2004.

, Muhammad 'Uṡmān, Istiṡmāru Amwāli al-Zakāh, Ru'yatu Fiqhiyyah Mu'āșirah Bahśu Damn Mawaḍ wa 'Āt al-Nadwah al-Śāliśah li Qaḍāyā al-Zakāh, , 506. al-Mu'āṣirah, Kuwait, 1992.

Yusuf Qardawi,Fiqh az-Zakāt (Hukum Zakat) Diterjemahkan oleh: Salman Harun, Muassasah ar-Risālah, Beirut, 1973.

Soerjono Soekanto dan Sri Mamudji, Penelitian Hukum Normatif Suatu Tinjauan Singkat, Rajawali Press, Jakarta, 2004. 
Syariful Alam. RRI. Maret 05, 2019. https://www.rri.co.id (accessed Agustus 17, 2020).

Teungku Muhammad Hasbi Ash-Shidiqie, Pedoman Zakat, PT. Pustaka Rizki Putra, Semarang, 1999.

, Pengantar Penelitian Hukum, 49, 53 dan 96. UI Press, Jakarta, 1982. Undang-Undang Dasar 1945, Pasal 34, Ayat 1 s.d. 3.

UU R.I. No. 40 Tahun 2004, tentang Sistem Jaminan Sosial Nasional. " Bab 1 Ketentuan Umum, Pasal 1 ayat (1)." Oktober 29, 2004: 1. 